\title{
Information Era: The Crises of the Transition
}

\author{
Abbas Strømmen-Bakhtiar \\ Centre for Enterprise Architecture and Information Systems, \\ Bodø Graduate School of Business, University of Nordland, \\ Bodø, Norway
}

\section{Abbas.Strommen-Bakhtiar@uin.no}

\begin{abstract}
This paper examines the concept of 'era' as seen through the three sector hypothesis lens. It traces the birth of each era through a technological revolution and argues that we are currently in the transitional period between the Service Era and the Information Era. This transition, it is argued, also coincides with the turning-point of the sixth technological revolution (the Internet), which is amplifying the effects of both transitions (sectoral and technological), leading to an increasing social, political and economic dislocation. However, technology is neutral in itself and its deployment is determined by the political-economic philosophy of the country or the region where it is deployed. Therefore, it is argued that the current social, political and economic crisis is caused by the current economic philosophy which advocates primacy of capital and extreme individualism.
\end{abstract}

Keywords: Three sector hypothesis, Industrial Revolution, Information Era, Technological Revolution, Offshoring, Outsourcing, Globalization, the Internet, Transitional Period, Capitalism.

\section{Introduction}

It seems that at least since 1771 , every 50 years or so world witnesses a technological revolution that impacts the lives of people in profound ways. It is claimed (Perez, 2002a) that until 1971 the world has experienced five of these revolutions, each presenting new opportunities and threats. Each revolution affects the way we work, communicate and interact with each other. Sometimes the effects are so pronounced that it forces a reorganization of social structures, forms of government and a rethinking of fundamental beliefs and values.

What we see today, the unfolding global financial crisis, political crisis, rising unemployment, the ever-present danger of small wars turning into world wars, the general insecurity and fear of what the future will bring, all of these, is only a prologue to the fundamental reorientation that has to take place to facilitate the shift from one era to the next. We are in the transition from a Service Era to an Information Era.

Material published as part of this publication, either on-line or in print, is copyrighted by the Informing Science Institute. Permission to make digital or paper copy of part or all of these works for personal or classroom use is granted without fee provided that the copies are not made or distributed for profit or commercial advantage AND that copies 1) bear this notice in full and 2) give the full citation on the first page. It is permissible to abstract these works so long as credit is given. To copy in all other cases or to republish or to post on a server or to redistribute to lists requires specific permission and payment of a fee. Contact Publisher@InformingScience.org to request redistribution permission.
Transitions are, by definition, periods filled with uncertainty and fear. These are periods when large segments of the population shift jobs, when old knowledge loses its value, when we sail in uncharted waters full of possibilities and dangers. It is the time when the old era is still pulling us back with the promises of certainty and familiarity while the 
new era is pushing us forward with the lure and possibilities of the new.

Each era is born with a technological bang that sets in motion a series of technological explosions that heralds the birth of the new era. Each innovation gives birth to new invention, which once introduced into the society takes a life of its own. The cumulative effects of these inventions and technologies become the currents that push us in directions that we have hardly ever dreamt of.

However, it is not preordained that we must always follow the way things evolve. We determine how these inventions are used. Technological revolutions follow a simple life cycle of development and deployment, with a pause in the middle. This pause period is the period in which we decide how we are going to deploy these technologies. We set the direction of future deployments.

A cursory glance at the technological revolutions since the first industrial revolution of $1760 \mathrm{~s}$ shows that economic concerns have been the main arbiter of how new technologies have been deployed. The social consideration had never been taken into account nor are they being considered even now.

This paper examines the concept of 'era' as seen through the three sector hypothesis lens. It traces the birth of each era through a technological revolution and argues that the essence of the current information era is globalization supported by neo-liberal economic thoughts and philosophy. It further argues that we are in the transition period both in terms of the transition of eras and the full deployment of information technologies.

This paper is organized into the following sections: the next section (after introduction) presents the three sector hypothesis, and the related technological revolutions responsible for changes within each sector, the creation of the new quaternary or information sector and the birth of the Information Era. The third section discusses the second technological revolution of the Information Era which has triggered the transition period. The fourth section briefly examines the previous transition period (Industrial Revolution). Section five discusses the new transition period (our current transition). Section five is composed of four subsections. Subsection one looks at the underlying enabling technologies that facilitate the increase in international trade. Subsection two looks at the resulting global offshoring/outsourcing. Subsection three examines the supporting ideology of the globalization and subsection four looks at the effect of globalization and the Internet on the individuals. The final section presents the concluding remarks.

\section{From Farms to Factories to Offices to...}

Society is defined as "an organized group of persons associated together for religious, benevolent, cultural, scientific, political, patriotic, or other purposes" (Online Etymology Dictionary, 2010). As societies evolve, their social structure and their primary means of subsistence change. There are different views on how to categorize these social changes over time. Some base their categorization on time periods such as Pre-historical, Ancient, Middle Ages, Early Modern, Modern and Post-Modern; while others base their categorization on the advancements made in such areas as technology, communication and economy such as hunters and gatherers, simple agricultural, advanced agricultural, industrial, and special (e.g. fishing societies or maritime societies) (Lenski, 1984); still others who base their categorization on social inequalities (hunters and gatherers, Tribal, Stratified and Civilizations) (Elman, 1975).

Regardless of how we categorize the evolution of human societies; we cannot ignore one of the most important factors that, acting as glue, keeps a society together, giving it purpose and providing it with means of existence, namely its economy. The economy is those complex human activities that are concerned with the production, distribution, and consumption of goods and services 
(Collins English Dictionary, 2011). The economy also provides the members of the society with identities through the occupations that it provides.

Some such as Fisher (1939, 1952); Clark (1967); Fourastié (1950) and others used these economic activities or occupations as the basis for classification of both the economy and human history. They argued that an economy is composed of three sectors: primary, secondary, and tertiary. These sectors are defined according to the factors of production. For example, the primary sector contains agriculture, mining, and fishing, while the secondary sector is composed of all activities that are related to manufacturing of one kind or the other. The tertiary sector contains all the services that are needed by the society.

This division, Wolf (1955) argues, limits the increase in productivity in each sector. For example, the primary sector is dependent on natural growth factors; the secondary sector on mechanical factors and tertiary on relatively unaided human skill. In his book "The Grand Hope of the 21st Century" Fourastié (1950) states that it is the proportion of people employed in each sector that determines the era in which that society currently finds itself in (fig. 1). He argues that for most of human history, the majority of the working population had been working with agriculture or extraction of the raw materials (primary: $80 \%$, secondary: $10 \%$ and tertiary: $10 \%$ ). Then we had the industrial revolution and the beginning of the transition era (secondary or industrial). Here again he points to a major shift in employment away from the primary sector and towards the secondary sector.

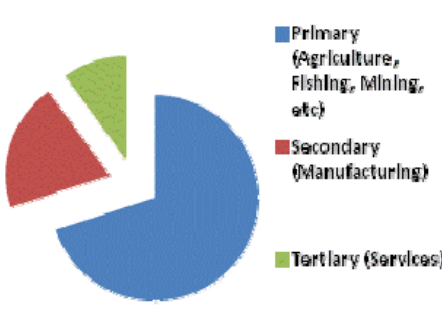

Tradditlonal Clvil|zation

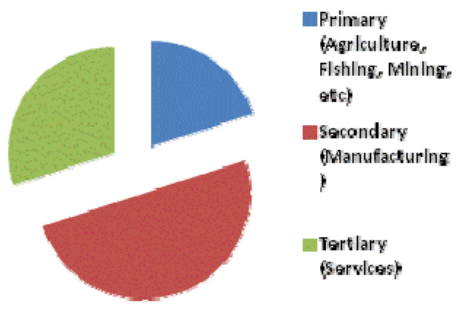

Transitional Perlod

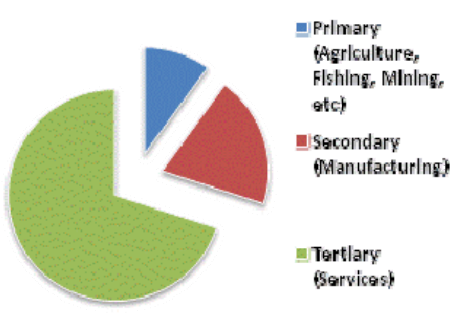

Tertlary Clvillzation

Figure 1. Three sector hypothesis

Fourastié foresaw the beginning of the service era in the 1950s, when industry would begin to show signs of saturation, which would result in a shift in the employment pattern away from manufacturing and towards the services. A cursory look at the available data (fig. 2) shows that his prediction of change in employment pattern from secondary to tertiary or service era has come true.

Fourastié also predicted that in the Tertiary Era the technological progress would not have any impact on the service sector; leading to stagnation in the technological progress, something that has proven to be wrong. It is here that Fourastiés vision of the future diverges from the reality of the potential for continuing technological progress. Indeed, instead of technological stagnation, we experienced the opposite, an intensification of technological advancement and progress. 


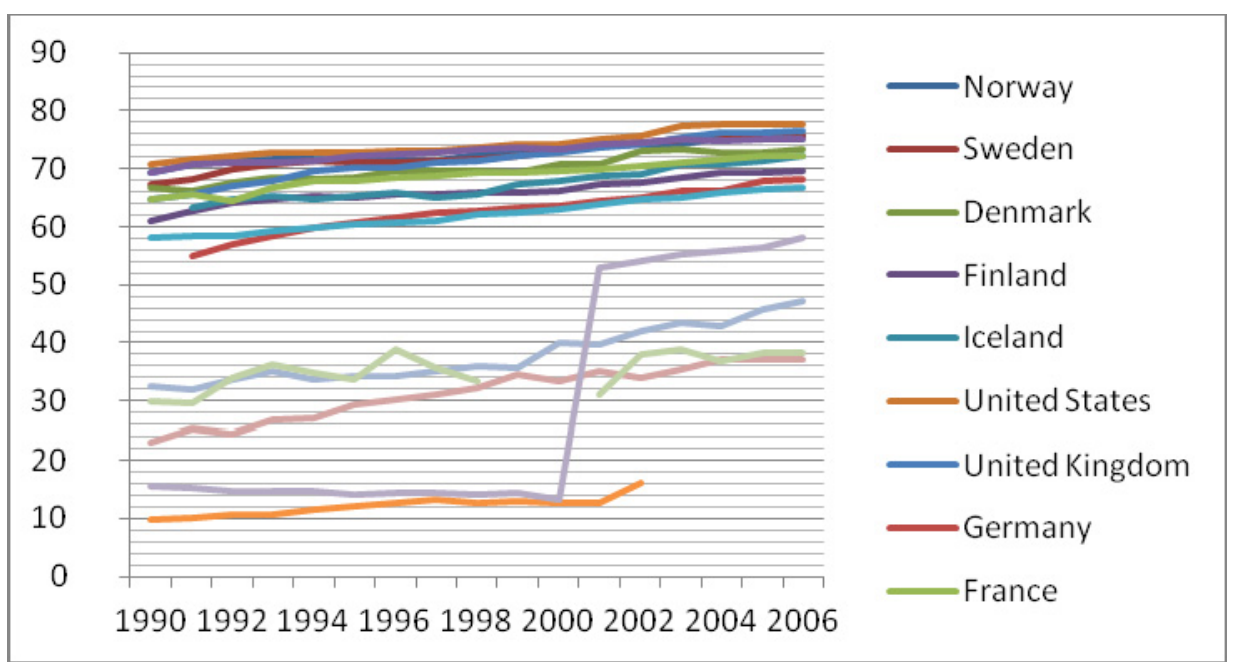

Figure 2. The growing dominance of the service sector in selected countries measured by the total employment share 1990-2007. Source: World Bank

At the height of the secondary or industrial period, in 1936, people such as Konrad Zue (19101995) were planting the seeds of the new era: the Information Era. In that year, Konrad Zue, a German engineer invented the ' $Z 1$ ', the first freely programmable computer (Bellis, 2009). By 1953, when the transition from secondary/industrial era to tertiary/service era was in full swing, IBM introduced the first commercial general-purpose computer, followed in 1958 by its first mainframe. In 1965, the American company Digital Equipment Corporation (DEC) introduced the mini-computer and by 1981, we had the Personal Computers (PCs). By mid 1980s, advances in telecommunication and networking technologies were paving the way for the next technosocial revolution akin to the first and second industrial revolutions. The advent of the Internet in 1991 (United States' National Science Foundation or NSF removed all restrictions on commercial use of Internet), starting the transition to the Information Era.

One must note that each revolution or transition is not caused by a single invention, event or an ideology. There are many factors from many different fields that converge to create a number of new technologies that impact the society in very profound ways. The adoption of these technologies by societies may then influence a new way of life, complete with new ideologies, social structures, methods of work and even cultures.

This may sound like technological determinism and to a certain extent it is; but it is the 'soft' determinism, meaning that we have the free will to use the technology in such a way as to determine the shape of our societies and living conditions. This is in contrast to the 'hard' determinism's vision of the future in which "we will have technologized our ways to the point where, for better or worse; our technologies permit few alternatives to their inherent dictates." (M. R. Smith \& Marx, 1994, p. xii)

History has shown the power of technology as a crucial agent of change, especially with regards to its effects on the society. For example, the industrial revolution (first and second) resulted in mass migration of people from farms to the cities, changing work environment, creation of trade unions and a host of other economic, social and cultural changes. Other technological revolutions have similarly impacted societies in profound ways. Perez (2002b) lists five technological revolutions since 1770s (presented in table 1), arguing that each revolution brings about "an upheaval in the whole fabric of the economy and of propelling a long-term upsurge of development" $(2002 \mathrm{~b}$, p. 8). This she argues tends to occur regularly at approximately 50 year intervals. 
Table 1. Technological revolutions and related innovation principles. Source: adapted from Perez (2002b)

\begin{tabular}{|c|c|c|}
\hline $\begin{array}{l}\text { Technological } \\
\text { revolution }\end{array}$ & $\begin{array}{c}\text { New technologies or } \\
\text { new redefined } \\
\text { industries }\end{array}$ & $\begin{array}{c}\text { Common-sense innovation } \\
\text { principles }\end{array}$ \\
\hline $\begin{array}{l}\text { First : The } \\
\text { 'Industrial } \\
\text { Revolution' (1771) }\end{array}$ & $\begin{array}{l}\text { Mechanized cotton industry, } \\
\text { wrought iron, Machinery }\end{array}$ & $\begin{array}{l}\text { Factory production; mechanization; } \\
\text { productivity/time keeping and time saving; } \\
\text { fluidity of movements (as ideal for machines } \\
\text { with water-power and for transport through } \\
\text { canals and other waterways); local networks. }\end{array}$ \\
\hline $\begin{array}{l}\text { Second: Age of } \\
\text { Steam and } \\
\text { Railways (1829) }\end{array}$ & $\begin{array}{l}\text { Steam engines and } \\
\text { machinery, railway } \\
\text { construction, rolling stock } \\
\text { production, steam power for } \\
\text { many industries }\end{array}$ & $\begin{array}{l}\text { Economies of agglomeration/industrial } \\
\text { cities/national markets; power centres with } \\
\text { national networks; scales as progress; } \\
\text { standard parts/machine-made machines; } \\
\text { energy where needed (steam); interdependent } \\
\text { movement (of machines and of means of } \\
\text { transport) }\end{array}$ \\
\hline \begin{tabular}{|l|} 
Third:Age of Steel, \\
Electricity and \\
Heavy Engineering \\
(1875)
\end{tabular} & $\begin{array}{l}\text { Cheap steel, full development } \\
\text { of steam engine for steel } \\
\text { ships, heavy chemistry and } \\
\text { civil engineering, electrical } \\
\text { equipment industry, copper } \\
\text { and bottled food, paper and } \\
\text { packaging }\end{array}$ & $\begin{array}{l}\text { Giant structures (steel); economies of scale of } \\
\text { plant/vertical integration; distributed power of } \\
\text { industry (electricity); science as a productive } \\
\text { force; worldwide neworks and empires } \\
\text { (including cartels); universal standardization; } \\
\text { cost accounting for control and efficiency; } \\
\text { great scale for world market power/'small' is } \\
\text { successful, if local }\end{array}$ \\
\hline $\begin{array}{l}\text { Fourth: Age of Oil, } \\
\text { the Automobile and } \\
\text { Mass Production } \\
\text { (1908) }\end{array}$ & \begin{tabular}{|l|} 
Mass-produced automobiles, \\
cheap oil fuels, \\
petrochemicals, internal \\
combustion engine for \\
automobiles, transport \\
tractors, airplanes, war tanks \\
and electricity, home electrical \\
appliances, refrigirated and \\
frozen foods \\
\end{tabular} & $\begin{array}{l}\text { Mass production/mass markets; economies of } \\
\text { scale (product/market volume/horizontal } \\
\text { integration; standardization of products; } \\
\text { energy intensity (oil based); synthetic } \\
\text { materials; functional specialization/hierarchical } \\
\text { pyramids; centralization/metropolitan centres- } \\
\text { suburbanization; national powers, world } \\
\text { agreements and confrontations. }\end{array}$ \\
\hline \begin{tabular}{|l|} 
Fifth: Age of \\
Information and \\
Telecommunication \\
s (1971)
\end{tabular} & $\begin{array}{l}\text { The information revolution: } \\
\text { cheap microelectronics. } \\
\text { Computers, software, } \\
\text { telecommunications, control } \\
\text { instruments, computer-aided } \\
\text { biotechnology and new } \\
\text { materials }\end{array}$ & $\begin{array}{l}\text { Information-intensity (microelectronics-based } \\
\text { ICT); decentralized integration/network } \\
\text { structures; knowledge as capital/intangible } \\
\text { value added; hetrogeneity, diversity, } \\
\text { adaptability; segmentation of } \\
\text { markets/proliferation of niches; economies of } \\
\text { scope and specialization combined with scale; } \\
\text { globalization/interaction between the global } \\
\text { and the local; inward and outward } \\
\text { cooperation/clusters; instant contact and } \\
\text { action/instant global communication }\end{array}$ \\
\hline
\end{tabular}

Each technological revolution, Perez argues, goes through four phases: Irruption, Frenzy, Synergy and Maturity. Irruption is the phase when the technological revolution begins, usually with a bang. In this phase, entrepreneurs and others begin to see the future potential of the new innova- 
tions. This is followed by'frenzy', when investors rush in to invest heavily in all possible alternative potentials of these new technologies. The investments in developing new infrastructure and technologies creates certain structural tensions within the existing system. All these activities also lead to financial speculation which in turn creates a financial bubble. The bubble soon bursts, creating a financial recession. There follows a period of circumspection (turning point), where investors, governments and users of the new technologies begin to re-evaluate their earlier thoughts, impressions and decisions. In this period standards and regulations are established, and new directions are charted. Now, the deployment period can begin with the 'synergy' phase, which heralds the acceptance of the new paradigm. This is followed by the 'maturity' phase when fewer and fewer technologies, products and innovations are introduced; leading to stagnation and eventually the end of that era.

Each era can contain one or more technological revolutions each building on or complementing the other. For example, the Transitional Era (Industrial Era) although initiated by the first Industrial Revolution, also contained the second and third technological revolutions as well (each taking approximately 50 years). Similarly, the Information Era most likely is composed of several technological revolutions of which we have witnessed one and are in the midst of the second.

Here, we have to consider that there may be a certain variation in dates. Perez (2002b) gives 1971 as the starting date of the Information Era, arguing that it was the availability of cheap microelectronics that started the technological revolution. One could argue that it was in 1953 and the introduction of the first commercial general-purpose computer by IBM that marked the beginning of the Era or the DEC's introduction of the first mini-computer in 1965. Regardless of which date we choose, we can be certain of one thing and that is: the second technological revolution started between 1991 and 1996 with the advent of the commercial Internet (Harris \& Gerich, 1996).

\section{Information Era's Second Technological Revolution}

Although it is relatively easy to pinpoint the advent of the Industrial Era (Transitional Period), it is rather difficult to state with any certainty the move to the Tertiary or Service Era. The Service Era was a natural by-product of the industrialization process which accelerated with the advent of mass production/manufacturing. When mass manufacturing and automation took hold, the living standards began to rise creating a demand for services that could be fulfilled by people no longer needed in the manufacturing sector. This dramatically increased the proportion of people working in the service sector, making the transition from Industrial Era to the Service Era. Glyn, et al., (1992) place this transition between 1960 and 1980. They state the following: "In this period the principal employment shift was towards services, with industrial share peaking and then falling between 1960 and 1981. Since productivity growth in industry was substantially higher than in services between 1950 and 1973, the output share of industry did not shift to the same extent as employment" (p. 43).

It must be noted that this transition didn't involve long-term unemployment or mass migration. This shift from secondary to tertiary era was a smooth transition, marked with stability and growth (table 2). 
Table 2. Annual rates of growth in Western Europe, 1955-75 (percent per year). Source: Temin $(2002$, p. 5)

\begin{tabular}{|l|c|c|}
\hline Austria & AUT & 4.3 \\
\hline Belgium & BLE & 3.3 \\
\hline Switzerland & CHE & 2.4 \\
\hline Germany & DEU & 3.4 \\
\hline Denmark & DNK & 3.2 \\
\hline Spain & ESP & 5.2 \\
\hline Finland & FIN & 3.8 \\
\hline France & FRA & 3.9 \\
\hline Great Britain & GBR & 2.1 \\
\hline Ireland & IRL & 3.2 \\
\hline Italy & ITA & 4.3 \\
\hline Netherlands & NLD & 3.4 \\
\hline Norway & NOR & 3.3 \\
\hline Portugal & PRT & 5.3 \\
\hline Sweden & SWE & 3.0 \\
\hline
\end{tabular}

As was mentioned previously Fourastié foresaw the beginning of the service era in the 1950s, predicting that in the Service era the technological progress would not have any impact on the service sector; leading to stagnation in the technological progress. He was right in predicting the timing of the transition, but wrong on the technological progress. The technological progress not only continued it accelerated. Many of the today's most important technologies find their genesis in this period.

In the 1970s, computers, along with microelectronics, were set to revolutionize the service sector. The invention, mass production and use of cheap microelectronic components along with mass deployment of mini-computers, not only accelerated the industrial automation process, but also began to lay the foundation for the automation of many activities within the service sector.

During this period (1960-1980), the manufacture, deployment and use of these computers and related software slowly gave rise to a completely new sector: the quaternary sector/ the information sector (Bell, 1976). The main technological driving force of this sector was of course the computer, a device that was to revolutionize our way of life.

From the very beginning, the computer has borne the label "revolutionary." Even as the first commercial machines were being delivered, commentators were extolling or fretting over the radical changes the widespread use of computers would entail, and few doubted their use would be widespread. The computer directed people's eyes toward the future, and a few thousand bytes of memory seemed space enough for the solution of almost any problem. On that both enthusiasts and critics could agree. Computing meant unprecedented power for science, industry, and business, and with the power came difficulties and dangers that seemed equally unprecedented. By its nature as well as by its youth, the computer appeared to have no history. (Mahoney, 1988, p. 14)

By late 1980s, computers (now in the form of ubiquitous Personal Computers) were adopted by people and organizations without any hesitation. It took nearly 50 years (1936 Z computer-1983 
Information Era

the first PC clone by Compaq) for this device to become a necessity for the businesses and a household gadget for the people. PCs were the Information Era's Model "T" Ford automobile, affordable and functional. The constant increase in the processing power combined with an equally constant reduction of hardware prices had made the PCs not only the 'must have' device, but the 'can have' device as well.

During this period, there was a surge in investments in infrastructure and related services. Networking was one of the main areas where the computer and telecommunication companies along with governments were cooperating to create the required Information Era infrastructure.

By mid 1980s, PCs had to a certain extent broken the shackles of the mainframes, minicomputers (and servers), empowering the users. But both private and commercial users needed to communicate with each other. By this time, companies had begun in earnest to network their PCs creating closed systems. By late 1980s, there were many islands of networked computers around the world. In 1991, these islands were given the opportunity to connect and interact, creating an ever expanding network of networks. The internet had finally arrived and with it, the second revolution of the Information Era. The internet required a host of new technologies, especially the infrastructure that was going to merge telecommunication with computers.

As is the case with every technological revolution, there was a rush to take advantage of all the possible opportunities that these new technologies promised. Before long, anyone with an idea around the internet technologies could raise millions in venture capital. Companies with only an idea and a 'dot com' at the end of their company's name suddenly were worth billions. By 1995, an Internet bubble was forming and a mad rush to cash in was in full swing. On Friday, March 10, 2000 , the bubble burst destroying many young companies, leaving behind only those that had sound business models and products. However, the crash didn't stop the revolution. After a year or two of consolidation, the innovation continued unabated; this time with mobility as the centre of attention.

Since then, we have begun to see the dying gasps of the PC and the birth of the mobile computing gadgets along with a host of new technologies and services; all of which have and are changing the way we work, communicate and relate to each other. All these changes are creating new opportunities as well as problems; problems that are tearing at the very fabric of many states and communities.

Old rules are hastily being revised to address emerging problems of capital mobility, financial speculations, increasing offshoring/outsourcing, increasing unemployment, debt both private and sovereign, increasing Gini coefficient (inequality of income), and a host of other problems.

All these problems are signs of the state of transition, when we are forced to rethink and reconsider our existing systems (ideology, government, economic systems, rules and regulations, even relationships). This is nothing new. It has happened before and will happen again. A brief look at the early effects of the Industrial Revolution (the first 100 years) will tell us that our situation is not unique in history.

\section{Transition: Industrial Revolution}

It is always difficult to pinpoint an exact date of the transition from one era to the next. There is never a single date, but rather a period of time in which the effects of technology and hence social change are felt by the society. For example, the English economic historian Arnold Toynbee (1884) tells us that 1760 was the 'eve' of the Industrial Revolution. In "Lectures on The Industrial Revolution in England," written in 1884, Toynbee sets out to describe the effects of the Industrial Revolution in England and how it had and was changing the English economy and hence the English society. 
Toynbee presents us with what he called the "chief features of the revolution" the essence of which he identified as the "substitution of competition for the medieval regulation" (1884, p. 26). This he contributed to the works of Adam Smith, Thomas Robert Malthus, David Ricardo and John Stuart Mill.

With regards to the effects of the Industrial Revolution he mentions the following changes: increasing population growth, increasing urbanization, a pronounced decline in the percentage of the rural population, and a marked reduction in the number of small farms. With regard to the effects of the Industrial Revolution, he mentions the "substitution of factory for the domestic system" (1884, p. 28) which he contributed to the invention of Spinning-Jenny (multi-spool spinning frame for producing yarn), Waterframe (spinning frame), Crompton's mule (machine used to spin cotton), Self-acting mule in cotton manufacturing, and the steam engine. These inventions taken together marked the introduction of the factory system. In addition, other inventions and discoveries were also contributing to the ongoing revolution. The invention of smelting by pit-coal and later the application of the steam engine to blast furnace changed the iron industry. Similarly, the improvements in canals, roads and the introduction of the first railroad in 1830 facilitated a tremendous increase in commerce which in turn forced merchants to "collect weavers around them in great numbers, to get looms together in a workshop, and to give out the warp themselves to the workpeople"(1884, p. 29).

All these pointed to increasing dislocation of population and changes in the modes of work. We see here a huge migration of people from rural areas to the burgeoning cities and from working on the land or independently as small artisans to paid workers in factories and workshops. All these changes affected the way people lived and worked, requiring new sets of rules and regulations.

Rules and regulations are often created to address existing problems, usually after those problems have been identified (experienced) and deemed to be large enough to cause disturbances in society. As such, laws are seldom in place to address problems arising from technological revolutions. The essence of the Industrial revolution, as Toynbee stated, was the advent of capitalism. Capitalism, especially when unchecked, tends to amplify social problems, particularly when combined with technological revolutions. Increasing disparity of income, concentration of wealth, deterioration of working conditions and monopolization are a few side-effects of unbridled capitalism. Toynbee acknowledges this by stating that: "The effects of the industrial revolution prove that free competition may produce wealth without producing well-being. We all know the horrors that ensued in England before it was restrained by legislation and combination."(1884, p. 30)

But apparently he was too optimistic; for in 1891, seven years after Toynbee published his "Lectures on The Industrial Revolution in England," Pope Leo XIII released an encyclical (a letter sent to all churches and indicating high papal priority for an issue at a given time) titled "Rerum Novarum" (Latin for 'of New Things'), decrying the existing social system.

"In any case we clearly see, and on this there is general agreement, that some opportune remedy must be found quickly for the misery and wretchedness pressing so unjustly on the majority of the working class: for the ancient workingmen's guilds were abolished in the last century, and no other protective organization took their place. Public institutions and the laws set aside the ancient religion. Hence, by degrees it has come to pass that working men have been surrendered, isolated and helpless, to the hardheartedness of employers and the greed of unchecked competition. The mischief has been increased by rapacious usury, which, although more than once condemned by the Church, is nevertheless, under a different guise, but with like injustice, still practiced by covetous and grasping men. To this must be added that the hiring of labour and the con- 
Information Era

duct of trade are concentrated in the hands of comparatively few; so that a small number of very rich men have been able to lay upon the teeming masses of the labouring poor a yoke little better than that of slavery itself" (Pope Leo XIII, 1891, p. 1).(Pope Leo XIII, 1891, p. 1)

\section{The New Transition: From Local to Global From Group to Individual}

If we, like Toynbee, were going to identify the essence of the Information Era and its latest technological revolution, it would be the 'Globalization'; supported by a new type of capitalism popularly referred to as 'neoliberalism' which emphasizes free trade and individual liberty.

Globalization and neoliberalism have been the driving force behind international trade and relations for the past 30 to 40 years. They have changed and are changing, the way we work, interact and view ourselves. Neoliberalism, especially with its emphasis on individual supremacy over the group has created tremendous social discord across the economically advanced societies. Its constant push for deregulation, de-unionization, the dismantling of social safety-nets and the recreation of class-based society (based on wealth and income) has brought back the fear of pauperism. Next we will discuss the underlying mechanism and enabling technologies and ideologies for both.

\section{Transition: From Local to Global}

The effects of globalization are now apparent in all aspects of our lives, from financial to cultural. It has taken almost three decades (1970-2000) for the effects to be properly felt and acknowledged. By the turn of the millennium, it was apparent to all that despite all the promises made by the proponents, globalization was changing the world in ways that were not always pleasant. It was with this in mind that the General Assembly of the United Nations in their Millennium Report spoke of the globalization. In paragraph 5 of their report, they stated the following:

"We believe that the central challenge we face today is to ensure that globalization becomes a positive force for all the world's people. For while globalization offers great opportunities, at present its benefits are very unevenly shared, while its costs are unevenly distributed. We recognize that developing countries and countries with economies in transition face special difficulties in responding to this central challenge. Thus, only through broad and sustained efforts to create a shared future, based upon our common humanity in all its diversity, can globalization be made fully inclusive and equitable. These efforts must include policies and measures, at the global level, which correspond to the needs of developing countries and economies in transition and are formulated and implemented with their effective participation."(United Nations, 2000)

It must be noted here that the term globalization is a rather nebulous and often misunderstood term. When writing about globalization, academics and sometime even professionals, try, for the sake of clarity, to define this term before presenting their arguments (something that General Assembly apparently forgot).

Globalization can mean different things to different people, depending on one's perspective. For example, from the financial point of view, we see Soros (2002, p. 1) defining globalization as "the development of global financial markets, the growth of transnational corporations, and their increasing domination over national economies"; while from the social point of view, Archibugi \& Iammarino (2002, p. 98) define globalization as "the intensification of world-wide social rela- 
tions, which link distant localities in such a way that local happenings are shaped by events occurring many miles away and vice versa."

There are other definitions each looking at globalization from a particular angle or what Ulrick Beck (2000) calls different dimensions of globalization. He lists these dimensions as: communication technology, ecology, economics, work organization, culture and civil society. He argues that any definition of globalization should include these dimensions.

Following his advice, we use the definition provided by the Levin Institute of the State University of New York, which defines globalization as a process that contains all the above-mentioned dimensions.

"Globalization is a process of interaction and integration among the people, companies, and governments of different nations, a process driven by international trade and investment and aided by information technology. This process has effects on the environment, on culture, on political systems, on economic development and prosperity, and on human physical well-being in societies around the world."("What is Globalization," n.d.)

The central point of this definition is of course the "international trade and investment aided by information technology." When we speak of international trade, we must consider the fact that international trade is directly affected by the economies of transportation, 99 percent of which (by weight) is transported by sea.

\section{Enabling Technologies: Containerization and ICT}

After the second and third industrial revolutions (steam, railway and steel), we saw a rapid increase in international trade. Historians (Knick Harley, 1989; North, 1968) link this rapid expansion to technological advances that resulted in marked decline in shipping costs. A similar increase in international trade is observed in the first and second technological revolutions (cheap electronics, increasingly powerful microprocessors, networking, mobility and the Internet) of the Information Era. Since 1970, we have seen a tremendous increase in international trade (fig. 4).

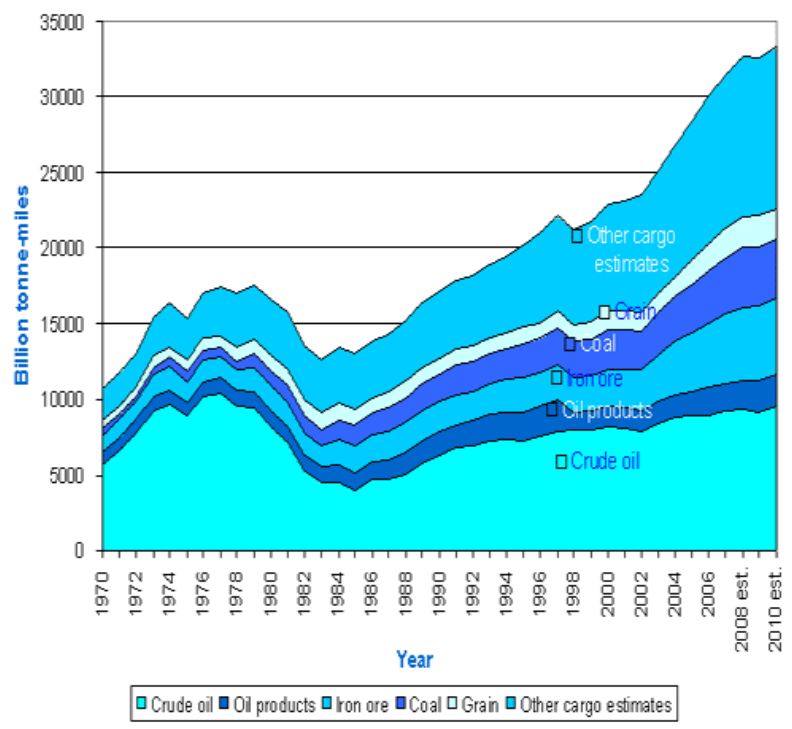

Figure 3. World Seaborne trade 1969-2010.

Source: (“Shipping and World Trade : Key Facts,” 2010) based on Fearnley's review 
This increase in international trade (mostly through shipping) has been made possible by two technological factors: containerization of cargo shipping and ICT. In 1955, Malcom P. McLean, a trucking entrepreneur from North Carolina, USA bought a shipping company for transporting trucks with their cargoes still in them. In this way, he thought the handling costs (loading and unloading) would be minimized. Later, he realized that a container that could be lifted and loaded would be an even better idea. A major part of the cost of shipping has always been the cargo handling from land transport to ships at the port of departure and back to trains or trucks at the other end. Containerization of cargo shipping changed all that making international trade, easier and in a sense more economical.

"In 1961, before the container was in international use, ocean freight costs accounted for 12 percent of the value of U.S. exports and 10 percent of the value of U.S. imports. According to the staff of the Joint Economic Committee of Congress, "these costs are more significant in many cases than governmental trade barriers," noting that the average U.S. import tariff was 7 percent.

This process was so expensive that in many cases selling internationally was not worthwhile. "For some commodities, the freight may be as much as 25 percent of the cost of the product," two engineers concluded after a careful study of data from 1959 (4). Shipping steel pipe from New York to Brazil cost an average of $\$ 57$ per ton in 1962 or 13 percent of the average cost of the pipe - not including the cost of moving the pipe from the steel mill to the dock (3). No wonder that, relative to the size of the economy, U.S. international trade was smaller in 1960 than it had been in 1950, or even in the Depression year of 1930 (5). The cost of conducting trade had risen so high that in many cases trade made no sense" (Levinson, 2006, p. 11).(Levinson, 2006, p. 11)

Containerization of cargo shipping has certainly helped in facilitating the increasing international trade by reducing the actual shipping costs, but the main enabling technology has been the ICT. Levinson (2006, p. 12) argues that "combined with the computer, the container made it practical for companies like Toyota and Honda to develop just-in-time manufacturing, in which a supplier makes the goods its customer wants only as the customer needs them and then ships them, in containers, to arrive at a specified time."

To reduce prices and introduce economies of scales, the container ships are being made larger and larger. Today, the amounts of cargo that can be carried by ships are simply incredible. For example, 'Xin Los Angeles' built by Samsung Heavy Industries in 2006 can carry 9600 TEU (Twentyfoot foot Equivalent Units) which is the equivalent of 1.3 million 29 inch color TVs or 50 million mobile phones (Hanlon, 2006). Since then the ships have been getting larger and larger. The most recently built ships like 'Emma Maersk' can carry 15000 TEU or more.

In response to increasing traffic and volume, the major ports have had to automate (using ICT). To handle tens of thousands of containers per day is not easy, especially when one considers the operations involved. The ship-to-shore transfer of containers is performed by quay cranes. Usually between one and four cranes are assigned to a particular ship (depending on its size). Each crane will be in charge of several columns of container storage slots along the ship. Each column has several levels. Once the container is lifted from the ship it is lowered onto a trailer for either storage on port's storage site, or transport to destination. The queuing of ships and trailers for loading and unloading of containers, tracking and controlling, examining and issuing transfer bills cannot be achieved without sophisticated computers.

In 2010, Port of Shanghai loaded and unloaded close to 80,000 containers per day or 55 containers per minute ("List of world's busiest container ports," n.d.). If the transfer of each container 
took only one minute longer, it would reduce the port's capacity by $50 \%$ or nearly 40000 containers. Large ports simply cannot function without the appropriate computerized systems.

Table 3. List of world's busiest container ports (traffic in thousands TEU). Source: ("List of world's busiest container ports," n.d.)

\begin{tabular}{|c|c|c|c|c|}
\hline Rank & Port & Country & 2010 & 2005 \\
\hline 1 & Shanghai & China & 29069 & 18084 \\
\hline 2 & Singapore & Singapore & 28431 & 23192 \\
\hline 3 & Hong Kong & China & 23699 & 22427 \\
\hline 4 & Shenzhen & China & 22510 & 16197 \\
\hline 5 & Bus an & S. Korea & 14194 & 11843 \\
\hline 6 & Nigbo & China & 13144 & 5208 \\
\hline 7 & Guangzhou & China & 12550 & 4685 \\
\hline 8 & Qingdao & China & 12012 & 6307 \\
\hline 9 & Dubai & UAE & 11600 & 7619 \\
\hline 10 & Rotterdam & Netherland & 11140 & 9287 \\
\hline
\end{tabular}

The containerization and ICT have eased the movement of goods from ship to truck or train through reduction of port costs and loading time.

Over time, shipping costs have become less of a barrier to international trade (fig. 5) and greater division of labour, encouraging offshoring and offshore outsourcing.

\section{Transition: Offshoring/Outsourcing and ICT}

Offshoring is different from offshore outsourcing in that in offshoring the company simply relocates a business process, such as manufacturing, to another country - still retaining ownership; while in offshore outsourcing, the business process is contracted out to another company in another country. The economic logic behind both strategies is the same: cost reduction, enabled by "revolutionary progress in communication and information technologies" (Grossman \& RossiHansberg, 2006, p. 1).

Today, people are concerned with jobs and hence do not differentiate between the two, using the word offshoring and offshore outsourcing to mean any form of activity that is performed outside of one's national boundary. In the Western Europe and North America, especially, it is equated with loss of jobs and lowering of standard of living. The American car industry is a good example of this. Until mid 1970s, this industry was a beacon of prosperity. By 1998, the offshoring/outsourcing had reduced the local production value to only 37 percent of the total.

"Thirty percent of the car's value goes to Korea for assembly, 17.5 percent to Japan for components and advanced technology, 7.5 percent to Germany for design, 4 percent to Taiwan and Singapore for minor parts, 2.5 percent to the United Kingdom for advertising and marketing services, and 1.5 percent to Ireland and Barbados for data processing. This means that only 37 percent of the production value ... is generated in the United States." (Grossman \& RossiHansberg, 2006, p. 2 citing WTO Annual Report (1998, p.36))

By the early 1980s, the reduction in shipping costs along with the advances in ICT made offshoring an extremely attractive proposition. Anything that could be put in a box could be offshored, which essentially meant all manufacturing goods. Corporations saw the attractiveness of low labour costs and lax regulations as a miracle, especially when at the time the labour costs were ris- 
ing rapidly in the advanced economies. For these corporations, it made sense to simply offshore the labour-intensive manufacturing activities to places where labour costs were extremely low. The whole offshoring activity was seen and is still perceived as an extension of Ricardo's "wine for cloth" comparative advantage argument. In his 1817 book On the Principles of Political Economy and Taxation, Ricardo argues that a nation should concentrate on producing goods that one can manufacture efficiently (as compared to others) and trade those goods for other goods that other nations produce more efficiently. Where Adam Smith argued for division of labour, Ricardo argued for production specialization. Ricardo's example of exchanging Portuguese wine for English cloth (Ricardo, 2004, p. 135) has been used as one of several justifications for offshoring of manufacturing.

The offshoring of manufacturing activities was also based on the idea that cheap, relatively unsophisticated goods such as toys and home appliances could be offshored, while highly complex and advanced products could be produced locally. It was also argued that loss of jobs in the manufacturing sector would be more than compensated by the rapid expansion of the service sector.

The resulting shift in output and employment in the industry sector of North America and Europe was extreme. For example, the US private industry output fell from $31.5 \%$ of total in 1965 to 16.6\% in 1997 ("The State of Manufacturing in the United States," 2010).

As was expected, the service sector saw a phenomenal expansion. According to the US International Trade Administration (ITA), from 1965 and 1997, services grew by 2,115 percent and finance, insurance and real estate grew by 1,473 percent (ibid). But services were not immune to offshoring or outsourcing either. The advances in ICT made offshoring of many services as attractive, if not more attractive, than the manufacturing activities or tasks. As Blinder (2006, p. 115) puts it:

"The old assumption that if you cannot put it in a box, you cannot trade it is thus hopelessly obsolete. Because packets of digitized information play the role that boxes used to play, many more services are now tradable and many more will surely become so. In the future, and to a great extent already, the key distinction will no longer be between things that can be put in a box and things that cannot. Rather, it will be between services that can be delivered electronically and those that cannot."

The advances in ICT, especially the networking and the advent of the Internet in the early 1990s, opened the way for offshoring/outsourcing of the services. Accounting, billing, back-office services were the first to be offshored / outsourced. Later, call centres and banking were added to the list, followed by software companies. The advent of Cloud Computing is the latest move in the outsourcing trend.

The advances in ICT technologies have opened the way for new methods of work, communication and interaction. We have seen that ICT along with containerization smoothed the way for international trade and offshoring/outsourcing. But as with all technological advances or revolutions, there must also be an ideological foundation to guide the direction in which these new technologies are employed.

Toynbee contributed the ideological changes (Mercantilism to Capitalism) of Industrial Revolution to the works of people like Adam Smith, Thomas Robert Malthus, David Ricardo and John Stuart Mill. Similarly, since 1970s, the works of people like Milton Freidman, Eugene Fama, and Grey Becker, (just to name a few) have strongly influenced the shape of our current political economy and philosophy. They proposed a new form of capitalism, popularly referred to as the neoliberalism. 


\section{Ideological Transition: Neoliberalism}

Neoliberalism is an extended, and some would say the perversion of the Capitalism. It has been defined in various terms by different authors, but here we shall use the following definition:

"Neoliberalism is a theory of political-economic practices proposing that human well-being can best be advanced by the maximization of entrepreneurial freedoms within an institutional framework characterized by private property rights, individual liberty, unencumbered markets, and free trade. The role of the state is to create and preserve an institutional framework appropriate to such practices. The state has to be concerned, for example, with the quality and integrity of money. It must also set up military, defense, police, and juridical functions required to secure private property rights and to support freely functioning markets. Furthermore, if markets do not exist (in areas such as education, health care, social security, or environmental pollution), then they must be created, by state action if necessary. However, beyond these tasks the state should not venture. State interventions in markets (once created) must be kept to a bare minimum because the state cannot possibly possess enough information to secondguess market signals (prices) and because powerful interests will inevitably distort and bias state interventions (particularly in democracies) for their own benefit" (Harvey, 2007, p. 22).

By early 1970 s the global capitalism was facing severe problems. The recession of the 1973, combined with the Arab oil embargo and subsequent oil price increases created a situation (unemployment, inflation, strikes - see table 6 and figure 6) in which the capitalist system of the post-war era with its distinct Keynesian flavour was not able to handle. The breakdown of the compact between capital and labour resulted in many strikes. In Great Britain, the strikes of winter of 1978-1979 resulted in the defeat of the Labour government of James Callaghan and the coming to power of a Conservative government, led by Margaret Thatcher (1979-1990).

In the United States, similar circumstances prevailed. The recession of 1974-75 was to be followed by another recession in 1980. In 1980, Ronald Reagan, a Republican was elected as the 40th President of the United States (1981-1989).

Table 4. Unemployment in UK 1975-1984. Source: Blanchflower and Millward (1988, p. 721)

Percentage change in total employment, 1975-1984.

\begin{tabular}{lllll}
\hline & $\begin{array}{l}\text { Distribution } \\
\text { of employment } \\
\text { in } 1980 \\
(\%)\end{array}$ & $\begin{array}{l}\text { Employment } \\
\text { change } \\
1975-1980 \\
(\%)\end{array}$ & $\begin{array}{l}\text { Distribution } \\
\text { of employment } \\
\text { in 1984 } \\
(\%)\end{array}$ & $\begin{array}{l}\text { Employment } \\
\text { change } \\
1980-1984 \\
(\%)\end{array}$ \\
\hline All establishments & 100 & -3 & 100 & -10 \\
Private sector & 64 & -4 & 56 & -13 \\
$\quad$ Private manufacturing & 38 & -9 & 27 & -19 \\
Private services & 26 & +6 & 29 & -4 \\
Public sector & 36 & -2 & 44 & -6 \\
$\quad$ Nationalised industries & 6 & -15 & 8 & -11 \\
Public services & 30 & +2 & 36 & -5 \\
\hline
\end{tabular}

Base: Establishments where $1975 / 1980$ employment size reported. Source: 1980/1984 Workplace Industrial Relations Survey. 
Information Era

A: Rates of Unemployment

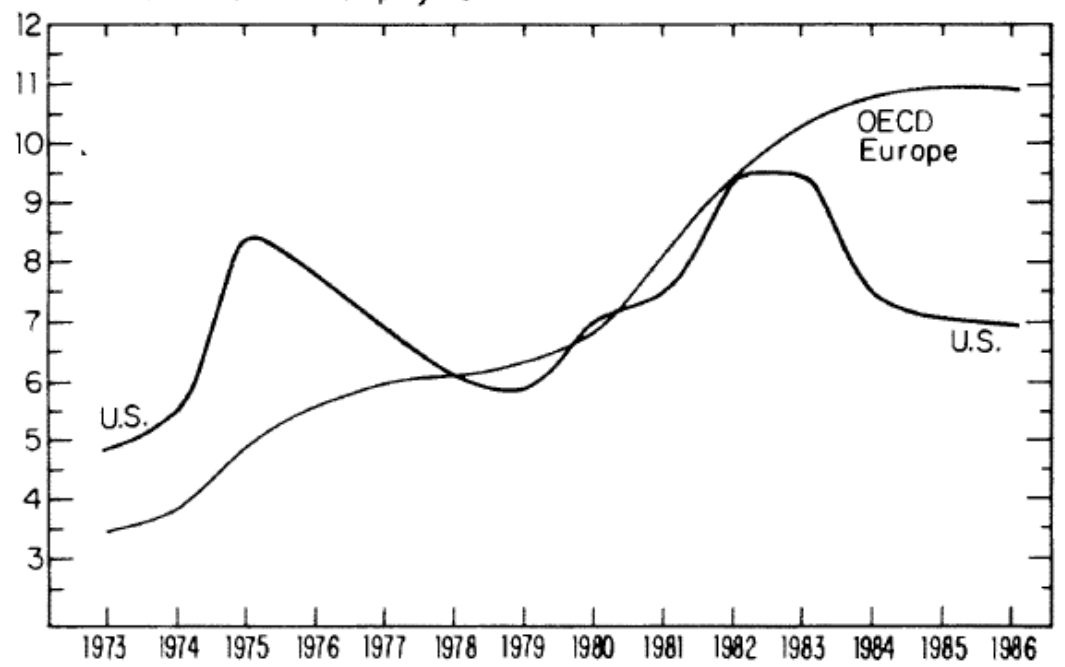

Figure 4. Unemployment: US vs. Europe (1973-1986). Source Freeman (1988, p. 295)

These two nations, one a superpower and the other an influential European middle power, set the tone for a new economic and social policy that would set the stage for the current financial crisis. Thatcher's ideas under the banner of Thatcherism and Reagan's under the banner of Reaganomics were based on their overwhelming opposition to state interference and taxes. As Erick J. Evans (2004, p. 3) explains, Thatcherism is for: "individual rights; private enterprise within a free market; firm, perhaps authoritarian leadership; low levels of personal taxation; union and vested interest bashing; simple patriotism." Reaganomics followed the same principles, only under the banner of supply-side economics. Reaganomics preached a scaling down of wasteful government activities, lower taxes and less interference with the market economy (Blanchard, Branson, \& Currie, 1987). The collapse of the Soviet Union in 1991 reinforced these ideas.

These ideas, of course, were not formulated by Thatcher and Reagan. They were the result of works done by people such as Milton Freidman, Eugene Fama, Grey Becker and others (the Chicago School) who tried to fill the void that was created by the failure of the Keynesian model (Jamie Peck, 2010). As Peck, Theodore, \& Brenner (2009, p. 50) explain:

"Neoliberalism first gained prominence during the late 1970s as a strategic political response to the declining profitability of mass production industries and the crises of Keynesian-welfarism. In response to the breakdown of accumulation regimes and established systems of governance, national and local states throughout the older industrialized world began, if hesitantly at first, to dismantle the basic institutional components of the postwar settlement and to mobilize a range of policies intended to extend market discipline, competition and commodification throughout society. In this context, neoliberal doctrines were deployed to justify, inter alia, the deregulation of state control over industry, assaults on organized labour, the reduction of corporate taxes, the downsizing and/or privatization of public services and assets, the dismantling of welfare programs, the enhancement of international capital mobility, and the intensification of inter-locality competition. Pinochle's Chile represented the first example of neoliberal 'shock treatment', while Thatcherism and Reaganism were amongst its defining, vanguard projects. More moderate and muted forms of a neoliberal politics have also been mobilized in traditionally social-democratic or Christian democratic states such as Canada, New Zealand, Germany, the Nether- 
lands, France, and Italy. Furthermore, following the debt crisis of the early 1980s, neoliberal programs of restructuring were extended selectively across the global South through the efforts of US-influenced multilateral agencies to subject peripheral and semi-peripheral states to the discipline of capital markets. By the mid-1980s, in the wake of this uneven but concerted realignment of policy agendas throughout the world, neoliberalism had become the dominant political and ideological form of capitalist globalization."

The main elements of the Neoliberalism can be named as free trade, individual liberty and minimum government interference. These elements were and are used effectively to deconstruct the welfare state and reinstate class power. In the West, it was done under the guise of more individual freedom and less government and taxes, while the rest of the world, especially the developing nations were prodded incessantly to adopt the same principles. This was done directly through advice (though at times it sounded like economic threats and coercion) or forced to acquiesce through supranational legal entities such as International Monetary Fund (IMF), World Bank and Word Trade Organization (WTO).

The aim was to force "national states and all other subordinate political institutions to adopt neoliberalized policy precepts in key regulatory spheres (for instance, trade, capital investment, labour, property rights)" (J. Peck et al., 2009, p. 335). This of course required a collective action; since the United States alone could not exert that much pressure on the entire world. This required "bringing Europe and Japan into alignment with the United States to shape the global financial and trading system in ways that effectively forced all other nations to submit " (Harvey, 2007, p. 33).“

Neoliberalism opened the Pandora's Box, letting loose corporations and capital (finance) in an increasingly unregulated and global market. The tremendous increase in offshoring/outsourcing was a direct result of increasing national and international market deregulation. And yes, technology certainly was an enabling factor but not the main driving force. The main driving force that defined the form and practice of globalization was the neoliberal ideology. Here by form and practice, it is meant the underlying demands of the neoliberal ideology: de-unionization, reducing the safety net for the poor and the vulnerable, reduction or abolition of subsidies, deregulation of nearly everything and privatization (Martinez \& Garcia, 1997); most of which were enacted to reduce the labour costs by forcing labour to accept lower wages.

In the absence of any meaningful regulations and labour organizations, the large corporations can and do move production from place to place, country to country in search of the cheapest labour, lowest taxes, and the weakest environmental and financial regulations. Indeed, in 2004, Diana Farrell, the then director of the McKinsey Global Institute, named some of these points as some of the important advantages of offshoring. Citing the consumer electronic industry as an example, she stated the following:

"Equally important, in most countries there are few governmental or organizational barriers - protectionist restrictions, tariffs, or union opposition- to prevent consumer-electronics companies from shifting various production processes from one nation to another."(Farrell, 2004, p. 3)

Closely connected to the offshoring is the free movement of capital. At first, free movement of capital was deemed necessary to facilitate the offshoring projects and increasing international investment and trade. However, soon technological innovations, especially within the ITC sector opened-up new horizons for the new global financiers. The new technologies created a new global, digital, networked financial market. Now it was possible for individuals and institutions to move massive amount of money at the speed of light from one corner of the earth to the other. Computerization of stock markets along with creation of novel financial instruments opened the 
door to a new type of venture capitalist; the type that was not so much interested in creating value than creating wealth. The speculation again became a respectable activity and this time everyone was encouraged to participate.

By 1992, the speculators were out in force speculating on the devaluation of various countries' currencies. For example, George Soros bet (shorted) $£ 10$ billion that British pound would be devaluated. This act (almost a self-fulfilling prophecy) forced the British central bank to devalue the pound by 20\%, earning Mr. Soros a fortune ("Official Web Site," n.d.). In 1997 the Asian economies were caught in a financial crisis in which many countries (e.g., Indonesia, Thailand, South Korea, Philippines, and others) were badly hurt. Hardly, ten years went by before another financial crisis emerged, this time in United States and Europe, with worldwide implications.

The neoliberal policies that encouraged deregulation, small government, globalization and supremacy of private capital has created a worldwide crisis of confidence in both the existing global capitalist system and the supranational agencies supporting it. People exceedingly are revolting against a system that although preaches individual liberty is, in essence, against democracy.

"Truth be told the connection between capitalism and democracy is tenuous at best. Capitalism and democracy obey different principles. The stakes are different: In capitalism wealth is the object, in democracy it is political authority. The criteria by which the stakes are measured are different. In capitalism the unit account is money, in democracy it is the citizen's vote. The interests are supposed to be served are different: In capitalism it is private interests, in democracy it is public interest."(Soros, 1998, p. 111)

It is interesting to note that George Soros is repeating what John Maynard Keynes was saying in 1926, namely that, what may be good for an individual may not be good for the society.

"Let us clear from the ground the metaphysical or general principles upon which, from time to time, laissez-faire has been founded. It is not true that individuals possess a prescriptive 'natural liberty' in their economic activities. There is no 'compact' conferring perpetual rights on those who have or on those who Acquire. The world is not so governed from above that private and social interest always coincide. It is not so managed here below that in practice they coincide. It is not a correct deduction from the principles of economics that enlightened self-interest always operates in the public interest. Nor is it true that selfinterest generally is enlightened; more often individuals acting separately to promote their own ends are too ignorant or too weak to attain even these. Experience does not show that individuals, when they make up a social unit, are always less clear-sighted than when they act separately" (Keynes, 1926, p. 6).(Keynes, 1926, p. 6)

\section{From Group to Individual}

The central tenants of the neoliberalism are the private property rights, the individual liberty, the unencumbered markets, and the free trade; all of which emphasize the primacy of individual over the group. The unfettered capitalism is based on the idea of individual self-love. It is, as Adam Smith argued, the self-love that promotes commerce and creates wealth.

"It is not from the benevolence of the butcher the brewer, or the baker that we expect our dinner, but from their regard to their own interest. We address ourselves, not to their humanity, but to their self-love, and never talk to them of our own necessities, but of their advantages. Nobody but a beggar chooses to de- 
pend chiefly upon the benevolence of his fellow-citizens."(A. Smith, 2005, p.

19)

This self-love, which in almost every major religion is considered a sin, is promoted by neoliberalism to be the natural state of human nature that should be embraced. The promotion of self-love has led to increasing individualism and consumerism. This extreme individualism is acting as a tremendous centrifugal force tearing the fabric of many societies. Individualistic slogans such as 'lower taxes', 'self-reliance', 'loving one's self in order to be able to love others', etc. are the mantras of this extreme individualism that is working against the concept of community and common welfare. This has resulted in a steady decline in what James Samuel Coleman (1994) calls the social capital (e.g., civic engagement and communal health). According to Hunout, Le Gall \& Shea (2003) since 1960s the Western societies have been descending into a deepening social recession. They argue that:

"From 1960, until the early 2000s, our countries slid into a deepening social recession that dwarfed the comparatively briefer economic recessions that often dominate news and politics. Since 1960, the divorce rate has doubled, the teen suicide rate has tripled, the recorded violent crime rate has quadrupled, the prison population has quintupled, the percent of babies born from unmarried parents has sextupled, cohabitation (a predictor of future divorce) has increased sevenfold, depression has soared - to ten times the pre-World War II levels, by one estimate" (2003, p. 2).

The extreme individualism has become part and parcel of the Western culture and is fast spreading to other cultures too. The individual and its hedonistic desires has become the main driving force behind the social order of consumerism, where every individual regards the self "as an end in himself" (Friedman \& Friedman, 1981, p. 159). This is reflected in every social stratum. It has especially had a very strong and destructive effect on the young people. Madeline Levine in "Challenging the Culture of Affluence: Schools, Parents, and the psychological Health of Children" addresses the effects of this culture of hedonism and extreme individualism on young college students. She states that:

"The primary reasons given by incoming students for wanting to go to college in the 1960s and early 1970s was, "to become an educated person," or "to develop a meaningful philosophy of life." Beginning in the 1990s, the most frequent reason given for attending college had changed to "make a lot of money," outranking not only the reflective reasons noted above, but also "becoming an authority in my field," or" helping others in difficulty." This shift in values is just one manifestation of a profound shift in American culture, away from values of community, spirituality, and integrity, and toward competition, materialism, and disconnection" (Levine, 2007, p. 2).

Figure 7 presents the decline in social capital from 1960 to 1995 . It should be noted that this decline correlates with the rise of neoliberalism and its emphasis in individualism. 

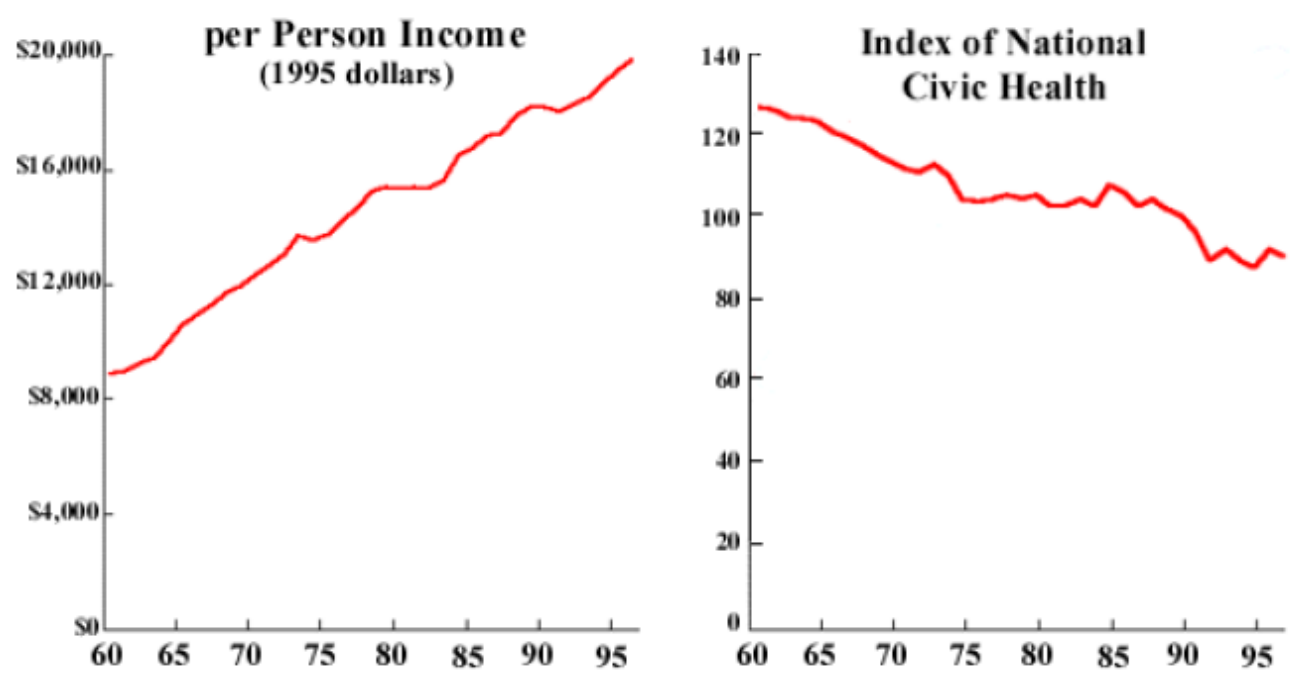

Figure 5. The decline of social capital. Source: Hunout, Le Gall \& Shea (2003, p. 2) excerpted from Myers D. G. (2000), The American Paradox, Spiritual Hunger in the Age of plenty.

The Internet has provided an excellent place for this individualism, which in turn has accelerated this social disconnection. The Internet is claimed correctly to have brought people together in virtual communities, but it is also contributing heavily to the atomization of the family unit, creating a real sense of loneliness or what Sherry Turkle (2011) describes as being 'alone together'.

"Technology is seductive when what it offers meets our human vulnerabilities. And as it turns out, we are very vulnerable indeed. We are lonely but fearful of intimacy. Digital connections and the social robot may offer the illusion of companionship without the demands of friendship. Our networked life allows us to hide from each other, even as we are tethered to each other. We would rather text that talk."(2011, p. 1)

Our identities, our very perception of who we are and our most intimate desires, are increasingly being shaped, not by our immediate family, friends and community, but by the virtual world(s) created in the cyberspace.

In social identity theory and identity theory, one sees one's self as an object that can be classified in relation to other social categories or classifications. This process is called the selfcategorization (Turner, Hogg, Oakes, Reicher, \& Wetherell, 1987) or identification (McCall \& Simmons, 1978), through which an identity is formed. Identity theory is concerned with the individual's role-related behaviour, while social identity theory is concerned with group processes and inter-group relations. Both theories focus on the multi- faceted and dynamic self that mediates the relationship between social structure and individual behaviour.

An identity is formed through self-categorization, which is made possible through contacts and membership in the family unit, community, work, civic societies, voluntary organization, etc. An individual plays different role in different situations and settings. These roles only have meaning in connection to the roles of others and the responses that they elicit. It is these responses that form the basis for developing a sense of self-meaning and self-definition. (Hogg, Terry, \& White, 1995)

"Having a particular social identity means being at one with a certain group, being like others in the group, and seeing things from the group's perspective. In contrast, having a particular role identity means acting to fulfil the expectations of the role, coordinating and negotiating interaction with role partners, and ma- 
nipulating the environment to control the resources for which the role has responsibility. Herein lies an important distinction between group- and role-based identities: the basis of social identity is in the uniformity of perception and action among group members, while the basis of role identity resides in the differences in perceptions and actions that accompany a role as it relates to counter roles"(Stets \& Burke, 2000, p. 226).

The Internet has affected both the self-identity and the social identity in important ways. Family, for example, plays an important role in shaping one's identity, especially in the formative years. The Internet is contributing heavily in atomizing the family unit. A study carried out by Kraut et al (1998) found that increased internet usage is associated with decline in communication with family members in the household, decline in the size of their social circle, and increase in their depression and loneliness. In 2000, Nie and Erbing (2000) carried out a study in the US which also reported that internet users spent less time with their family and friends than non-users. A follow-up study by Nie, Hillygus, \& Erbring (2002) confirmed their earlier results. In addition, the Internet is addictive (Christakis, 2010; Young, 1998), something that is creating an increasing problem for families.

However, as the Internet is atomizing the family unit, it is bringing individuals across the world closer together in virtual communities. In this respect, the Internet has brought 'people' closer. Collaboration, exchange of ideas, focusing on global problems and challenges are some of the advantages of the Internet. Cyberspace doesn't discriminate; it is open and inclusive. It is a place where anyone can find a community or if one is not found, then one can create one. It is a place where people can find fellow travellers and engage in all manners of discussions and activities of mutual interest and benefit. It is opening cultures and societies to "the others". Formal borders do not exist. Everyone is a one's neighbour; and as neighbours we tend to influence one another.

Slowly, but surely the Internet is influencing cultures and norms, giving rise to a new globalized culture. The effects are slowly being felt across the globe. Jeffrey Jensen Arnett (2002, p. 779) argues that because of the effects of globalization people are most likely to "develop a bicultural identity that includes a local identity." This local identity is rooted in their local culture while another part stems from an awareness of their connection to the global culture. Here, he points out that there are signs of increasing identity confusion, especially in the non-Western cultures. "As local cultures change in response to globalization, some young people find themselves at home in neither the local culture nor the global culture" (2002, p. 777). Here, we must reconsider Arnett's claim that this identity confusion is mostly affecting young people with "non-Western-culture". A closer look at the flourishing Western sub-cultures on the Internet, especially the extremist groups, is surely indicative of this identity confusion in the Western culture as well.

But it takes time for this bicultural identity to really take shape. Meanwhile, this sudden closeness, this close embrace, this peering into and trying to understand other cultures and identities that are shaped by them is creating conflicts. Individuals in various countries may live physically far from each other and yet on the Internet, they are neighbours. With physical distance and anonymity comes the decline of (false or true) civility; the civility that one affords one's neighbour. These rules of social engagement and cultural norms are the foundations on which tolerance and social peace are built. As Slavoy Zizek (2009, p. 50) explains, "nowhere is this disintegration of the protective walls of civility more palpable than in the clashes of different cultures." He goes on to warn that:

"Those who understand globalization as an opportunity for the entire earth to be a unified space of communication, one which brings together all humanity, often fail to notice the dark side of their proposition. Since a Neighbour is, as Freud suspected long ago, primarily a thing, a traumatic intruder, someone whose dif- 
Information Era

ferent way of life (or, rather, way of jouissance materialised in its social practices and rituals) disturbs us, throws the balance of our way of life off the rail, when it comes too close, this can also give rise to an aggressive reaction aimed at getting rid of this disturbing intruder. As Peter Sloterdijk puts it: 'More communication means at first, above all, more conflict'. This is why he is right to claim that the attitude of 'understanding each-other's way, by maintaining an appropriate distance, by implementing a new 'code of discretion' " (2009, p. $50)$.

\section{Conclusion}

During the past 260 years or so, we have experienced six technological revolutions, each affecting the way we live, work and interact with each other. Each technological revolution has affected the existing techno-economic paradigm by providing the means for modernizing all the existing industries and activities. The process of diffusion of both the revolution and its paradigm across the economy has resulted in a series of surges of development (Perez, 2002a), which in turn has changed not only the way we work and communicate, but also our fundamental beliefs, cultures and identities.

We have seen how the first industrial revolution started the process of mass migration of people from farms and countryside to the cities; how it and the subsequent technological revolutions of the 1800 and early 1900 gave rise and solidified the capitalist economic system; and how these early technological revolutions affected societies and systems of international trade and power.

These early technological revolutions put an end to the agricultural / primary Era and heralded the arrival of the secondary / Industrial Era. This transition took many years and resulted in many wars and unimaginable suffering for millions of people; while at the same time brought with it tremendous opportunities. By 1900, Europe had risen to dominate the globe, followed closely by the United States.

By 1950, the industrialization process that had started almost 200 years earlier had matured and was giving way to the Service Era, which was a natural by-product of the increasing automation of manufacturing processes and the subsequent increase in living standards.

Contrary to the first transitional period, the transition from industrial to service era was a smooth one. The period between 1950 to the early 1970s was a period of stability and growth. It was the golden age (Glyn et al., 1992; Temin, 2002). But it lasted only a short time before another technological revolution (cheap electronics and microprocessors) happened.

Today, we mark the early 1970s as the beginning of the transition to the Information Era. The advent of commercial Internet in the early 1990s accelerated the pace of this transition. Now after 50 years the effects of this transition are being felt across the world.

"The global financial crisis; the upheaval in business and labour markets resulting from a new international division of labour; the unstoppable growth of the global criminal economy; the social and cultural exclusion of large segments of the population of the planet from the global networks that accumulate knowledge, wealth, and power, the backlash of the disaffected in the form of religious fundamentalism; the rekindling of national, ethnic, and territorial cleavages, ushering in the negation of the other, and thus the widespread resort to violence as a way of protest and domination; the environmental crisis epitomised by climate change; the growing incapacity of political institutions based on nation-state to handle global problems and local demands; these are 
all diverse expressions of a process of multidimensional, structural change that take place in the midst of agony and uncertainty" (Castells, 2011, p. I)

We have finally reached the critical point where the old (economic, political and financial) systems can no longer address the existing and emerging problems. A good example of this is the exclusive economic club of G7 (Group of Five: France, Germany, Italy, Japan, the United Kingdom, Canada and the United States) which until 1999 and the creation of G20 was the main forum for finding common solutions to global economic problems. By 2009, the G7 was no longer arbiter of world economic direction. Indeed, by this time the financial crisis had so weakened the G7 countries that they appealed to the BRICS (Brazil, Russia, India, China and South Africa) countries and the rest of the G20 (Group of 20 countries) for help. Indeed, it is estimated that by 2050, the BRIC countries will be leading the world economy (Ogrean \& Herciu, 2010).

Other international organizations such as International Monetary Fund (IMF), World Bank, United Nations, the Internet Corporation for Assigned Names and Numbers (ICANN), Society for Worldwide Interbank Financial Telecommunication (SWIFT) and others are under pressure to reorganize in such a way as to reflect this shift of power.

The shift in power doesn't, of course, happen overnight. It takes time, and the existing powers will resist with everything at their disposal to stop or reverse their decline; which usually result in wars. Transition periods are especially dangerous periods, since it is in these periods that nations take advantage of technological revolutions to advance their economic power. This newly acquired economic power give these emerging powers the necessary resources to challenge the older and established powers. Paul Kennedy, the American historian, argues that from 1500 to 2000 , productive economic forces have had the most crucial influences in outcome of all lengthy wars. It is the differentiated growth rates in the periods between the wars that causes the various powers to become relatively stronger or weaker (Kennedy, 1988, p. 694).

It is difficult to pinpoint an exact reason for the decline of the Western economic fortunes, but one can state with certainty, that it has not been caused by the lack of technological prowess. All of the past 6 technological revolutions were started in the West, and it is most likely that the next technological revolution will also start in the West as well; which leaves us with a prime suspect, namely the current economic-political philosophy.

Neoliberalism with its philosophy of individualism which in effect is a philosophy of 'rich deserves to get richer' and 'winner takes all' (Frank \& Cook, 2010; Frank, Cook, \& Rosen, 1996; McMahon Jr \& Abreu, 1998), has tried to mask the advancing of the interests of the super rich by wrapping it in slogan of individual liberty.

The internationalization of capital markets, advances in information technology, marked reduction in shipping costs, a change in governments' attitude towards labour unions and deregulation have combined to reduce wages in many lower level jobs in the West. As a result, many jobs that were created in the service industries were and are low-paying jobs; jobs that pay less than people need to live on (Appelbaum \& Bernhardt, 2006; Ehrenreich, 2008; Shulman, 2011). And as though this was not enough, the workers are forced to compete in an international labour market, where wages are determined by the lowest wages possible, regardless of the cost of living or any other considerations.

This ruthless exploitation of workers and resources combined with increasing deregulation of capital markets has resulted in the unprecedented accumulation of tremendous wealth in the hands of few individuals and corporations. A recent study of 30 million economic actors contained in the Orbis 2007 database has revealed the existence of 147 super-entities that control 40 percent of total wealth of all listed companies. The majority of the top 50 are Western companies (Vitali, Glattfelder, \& Battiston, 2011). 
Information Era

As the recent events have shown, the accumulation of so much wealth in so few hands hasn't made capital more available for productive investment. To the contrary, it has increased the appetite of the wealthy for even higher risks.

Today's financial crisis is not really a purely "financial" crisis. It is much more than that. It is the crisis of confidence in the old system. It is the crisis of confidence in the political system. It is the crisis of individual and group identity. It is the crises that always come with the age of transition when the old beliefs, assumptions and systems are shown to be inadequate. What is needed is a new political-economic philosophy; one, that not only addresses the requirement of the new globalized market, but also and most importantly, the ethical requirements.

\section{References}

Appelbaum, E., \& Bernhardt, A. D. (2006). Low-wage America: How employers are reshaping opportunity in the workplace. Russell Sage Foundation Publications.

Archibugi, D., \& Iammarino, S. (2002). The globalization of technological innovation: Definition and evidence. Review of International Political Economy, 9(1), 98-122.

Arnett, J. J. (2002). The psychology of globalization. American Psychologist, 57(10), 774.

Beck, U. (2000). What is globalization? Polity.

Bell, D. (1976). The coming of the post-industrial society. The Educational Forum, 40, 574-579.

Bellis, M. (2009). Inventors of the modern computer: The first freely programmable computer invented by Konrad Zuse. Retrieved October, 4, 2009, from http://inventors.about.com/library/weekly/aa050298.htm .

Blanchard, O. J., Branson, W., \& Currie, D. (1987). Reaganomics. Economic Policy, 2(5), 15-56. doi: $10.2307 / 1344620$

Blanchflower, D., \& Millward, N. (1988). Trade unions and employment change. European Economic Review, 32, 717-726.

Blinder, A. S. (2006). Offshoring: The next industrial revolution? Foreign Affairs, 85(2), 113-128. doi: $10.2307 / 20031915$

Castells, M. (2011). The rise of the network society: The information age: Economy, society, and culture. John Wiley \& Sons.

Christakis, D. (2010). Internet addiction: A 21st century epidemic? BMC medicine, 8(1), 61.

Clark, C. (1967). The conditions of economic progress. London: MacMillan.

Coleman, J. S. (1994). Foundations of social theory. Belknap Press.

Ehrenreich, B. (2008). Nickel and dimed: On (not) getting by in America. Holt Paperbacks.

Elman, S. R. (1975). Origins of the state and civilization: The process of cultural evolution. W. W. Norton \& Company, Inc.

Evans, E. J. (2004). Thatcher and Thatcherism. Routledge.

Farrell, D. (2004). Beyond offshoring. Harvard Business Review, 82(12), 82-90.

Fisher, A. G. (1939). Production, primary, secondary and tertiary. Economic Record, 15(1), 24-38.

Fisher, A. G. (1952). A note on tertiary production. The Economic Journal, 820-834.

Fourastié, J. (1950). Le grand espoir du XXe siècle: progrès technique, progrès économique, progrès social. Presses universitaires de France.

Frank, R. H., \& Cook, P. J. (2010). The winner-take-all society: Why the few at the top get so much more than the rest of us. Virgin Digital. 
Frank, R. H., Cook, P. J., \& Rosen, S. (1996). The winner-take-all society. Journal of Economic Literature, 34(1), 133-134.

Freeman, R. B. (1988). Evaluating the European view that the United States has no unemployment problem. The American Economic Review, 78(2), 294-299.

Friedman, M., \& Friedman, R. (1981). Free to choose. Penguin Books.

Glyn, A., Hughes, A., Lipietz, A., \& Singh, A. A. (1992). The rise and fall of the golden age. The golden age of capitalism: Reinterpreting the postwar experience (pp. 39- 75). Oxford University Press, USA. Retrieved from http://lipietz.net/ALPC/EGM/EGM_1986j-en1.pdf

Grossman, G. M., \& Rossi-Hansberg, E. (2006). The rise of offshoring: It's not wine for cloth anymore. The New Economic Geography: Effects and Policy Implications, 59-102.

Hanlon, M. (2006, June 10). The world's largest container ship launched. gizmag.com. Retrieved November 26, 2011, from http://www.gizmag.com/go/5853/

Harris, S. R., \& Gerich, E. (1996). Retiring the NSFNET backbone service: Chronicling the end of an era. ConneXions, 10(4). Retrieved from http://www.merit.edu/networkresearch/projecthistory/nsfnet/nsfnet_article.php

Harvey, D. (2007). Neoliberalism as creative destruction. Annals of the American Academy of Political and Social Science, 610, 22-44.

Hogg, M. A., Terry, D. J., \& White, K. M. (1995). A tale of two theories: A critical comparison of identity theory with social identity theory. Social Psychology Quarterly, 58(4), 255-269. doi:10.2307/2787127

Hunout, P., Le Gall, D., \& Shea, B. (2003). The destruction of society: Challenging the 'modern' tryptique: Individualism, hedonism, consumerism. The International Scope Review, 5(9), 1-8.

Kennedy, P. M. (1988). The rise and fall of the great powers. Random House New York.

Keynes, J. M. (1926). The end of laissez-faire (Vol. 16). Hogarth Press London.

Knick Harley, C. (1989). Coal exports and British shipping, 1850-1913. Explorations in Economic History, 26(3), 311-338.

Kraut, R., Patterson, M., Lundmark, V., Kiesler, S., Mukophadhyay, T., \& Scherlis, W. (1998). Internet paradox: A social technology that reduces social involvement and psychological well-being? American psychologist, 53(9), 1017.

Lenski, G. E. (1984). Power and privilege: A theory of social stratification. The University of North Carolina Press.

Levinson, M. (2006). Container shipping and the economy: Stimulating trade and transformations worldwide. TR News, (246).

List of world's busiest container ports. (n.d.).Wikipedia: The Free Encyclopedia. Retrieved from http://en.wikipedia.org/wiki/World\%27s busiest_container_port

Mahoney, M. S. (1988). The history of computing in the history of technology. Annals of the History of Computing, 10(2), 113-125.

Martinez, E., \& Garcia, A. (1997). What is neoliberalism? A brief definition for activists. National Network for Immigrant and Refugee Rights, 1 .

McCall, G., \& Simmons, J. (1978). Identities and interactions: An examination of associations in everyday life (rev. ed.). New York: The Free Press.

McMahon Jr, M. J., \& Abreu, A. G. (1998). Winner-take-all markets: Easing the case for progressive taxation. Fla. Tax Rev., 4, 1.

Nie, N. H., \& Erbring, L. (2000). Internet and society. Stanford Institute for the Quantitative Study of Society. 


\section{Information Era}

Nie, N. H., Hillygus, D. S., \& Erbring, L. (2002). Internet use, interpersonal relations, and sociability: A time diary study. The Internet in everyday life, 213-243.

North, D. C. (1968). Sources of productivity change in ocean shipping, 1600-1850. The Journal of Political Economy, 76(5), 953-970.

Official Web Site of George Soros. (n.d.). Retrieved November 30, 2011, from http://www.georgesoros.com/faqs/archive/category/finance

Ogrean, C., \& Herciu, M. (2010). Changing the patterns of the global economy-The emergence and evolution of the Bric Countries. Studies in Business and Economics, 5(2), 100-110.

Peck, Jamie. (2010). Constructions of neoliberal reason. OUP Oxford.

Peck, J., Theodore, N., \& Brenner, N. (2009). Neoliberal urbanism: Models, moments, mutations. Sais Review, 29(1), 49-66.

Perez, C. (2002a). Technological revolutions and financial capital: The dynamics of bubbles and golden ages. Edward Elgar Publishing.

Perez, C. (2002b). Technological revolutions and financial capital: The dynamics of bubbles and golden ages. Edward Elgar Publishing.

Pope Leo XIII. (1891). On the condition of the working classes.

Ricardo, D. (2004). The works and correspondence of David Ricardo: Volume 1, On the principles of political economy and taxation. (P. Sraffa, Ed.) (Vols. 1-11, Vol. 1). United States of America: Liberty Fund, Inc.

Shipping and World Trade : Key Facts. (2010). Shipping and World Trade. Retrieved November 20, 2011, from http://www.marisec.org/shippingfacts/worldtrade/volume-world-trade-sea.php

Shulman, B. (2011). The betrayal of work: How low-wage jobs fail 30 million Americans and their families. New Press.

Smith, A. (2005). Wealth of nations. Wiley Online Library.

Smith, M. R., \& Marx, L. (1994). Does technology drive history? The dilemma of technological determinism. MIT Press.

Soros, G. (1998). The crisis of global capitalism: Open society endangered. PublicAffairs,U.S.

Soros, G. (2002). George Soros on globalization. New York, NY, USA: Publicaffairs.

Stets, J. E., \& Burke, P. J. (2000). Identity theory and social identity theory. Social Psychology Quarterly, 63(3), 224-237. doi:10.2307/2695870

Temin, P. (2002). The golden age of European growth reconsidered. European Review of Economic History, 6(01), 3-22.

The state of manufacturing in the United States. (2010, July).Internatio Trade Administration. Retrieved November 27, 2011, from http://trade.gov/manufactureamerica/facts/tg_mana_003019.asp\#P13_602

Toynbee, A., \& Jowett, B. (1884). Lectures on the industrial revolution in England: Popular addresses, notes and other fragments. Rivingtons.

Turkle, S. (2011). Alone together: Why we expect more from technology and less from each other. Basic Books.

Turner, J. C., Hogg, M., Oakes, P., Reicher, S., \& Wetherell, M. (1987). A self-categorization theory.

United Nations. (2000). The Millenium Declaration (Millenium Summit). New York: General Assembly. Retrieved from http://www.un.org/millennium/declaration/ares552e.htm

Vitali, S., Glattfelder, J. B., \& Battiston, S. (2011). The network of global corporate control. PLoS ONE, 6(10), e25995. doi:10.1371/journal.pone.0025995 
What is globalization. (n.d.).Globalization 101. Retrieved November 24, 2011, from http://www.globalization101.org/What is_Globalization.html

Wolfe, M. (1955). The concept of economic sectors. The Quarterly Journal of Economics, 69(3), 402.

Young, K. S. (1998). Internet addiction: The emergence of a new clinical disorder. CyberPsychology \& Behavior, 1(3), 237-244.

Zizek, S. (2009). Violence: Six sideways reflections (First Paperback ed.). Profile Books.

\section{Biography}

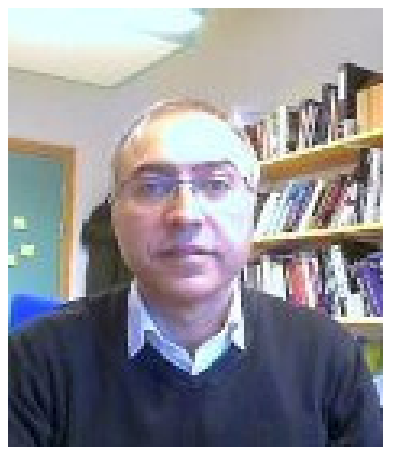

Abbas Strommen-Bakhtiar is an associate professor at the Centre for Enterprise Architecture and Information Systems, Graduate School of Business, University of Nordland. He has two BSc in Aerospace Engineering Technology and Computer Science, two MSc in Information Technology and Computer Integrated Manufacturing and a $\mathrm{PhD}$ in Strategic management. His main interests are in the areas of Management Information Systems and Strategic Management (including technology and innovation). He is currently working on several projects such as E-commerce, open source educational framework for Virtual University, the application and use of decision support systems in extreme environments. He also works as independent consultant. 